\title{
The influence on serum protein concentration of the protein intake in high-carbohydrate diets
}

\author{
BY BETTY L. COLES \\ Department of Physiology, Guy's Hospital Medical School, London SE I
}

(Received 6 November 1968-Accepted 20 December 1968)

\begin{abstract}
I. Healthy young men ate diets high in carbohydrate with a fixed protein content: $(a)$ I $8 \%$ protein with maize starch, $(b)$ I $8 \%$ protein with sucrose, $(c) 9 \%$ protein with sucrose. Sucrose or starch was given at a level of $7 \mathrm{~g} / \mathrm{kg}$ body-weight per day.

2. The serum albumin concentration fell by $7-10 \%$ after 16 days with all three diets; the falls were statistically significant. No change in $\gamma$-globulin concentration was seen with the $18 \%$ protein diets. With the $9 \%$ protein diet there was a significant increase in this fraction. The $\beta$-globulin concentration rose significantly with the diet containing $18 \%$ protein with sucrose but there was no change in this fraction with the other diets. $\alpha_{1}$ - and $\alpha_{2}$-globulins rose significantly with the diet containing $18 \%$ protein with sucrose but no increase in these fractions was seen on the other diets.

3. Possible mechanisms concerned in the production of these changes are discussed.
\end{abstract}

A decrease in serum albumin concentration and an increase in $\gamma$-globulin concentration have been shown to occur in healthy men eating a high-carbohydrate diet (Coles \& Macdonald, 1966). These changes resemble those seen in children with protein-calorie malnutrition and occurred despite an adequate protein intake. However, the amount of dietary protein in these experiments was not strictly controlled and varied from subject to subject. The present experiment was designed to test the effect on the serum protein concentration of variations in the protein intake of subjects on high-carbohydrate diets in which the carbohydrate content remained constant.

\section{EXPERIMENTAL}

The subjects were ten healthy male medical students weighing $6{ }_{3}-80 \mathrm{~kg}$. Three diets were used; the carbohydrate was either raw maize starch or sucrose, given at a level of $7 \mathrm{~g}$ carbohydrate per $\mathrm{kg}$ body-weight per day. The diets were adjusted so that protein provided $18 \%$ of the diet by weight. In the third diet, in which sucrose was the carbohydrate, the protein intake was halved and the diet was made isocaloric with the other two by the addition of cream. The protein in the diets was supplied as lean meat, chicken or fish. Green vegetables, salad and fresh or unsweetened tinned fruit were provided for each meal.

Specimen diets for $\mathrm{I}$ week containing $\mathrm{I} 8 \%$ protein and $9 \%$ protein respectively are shown in Tables I and 2. Daily vitamin supplements were given and each diet was eaten for a period of $\mathrm{I} 6$ days. The maize starch was eaten as a slurry in unsweetened lemon juice (PLJ; Pure Lemon Juice Co., Brentford, Middx) in divided doses and the sucrose was used on fruit and in drinks; any surplus was taken in lemon juice. Six subjects ate the diet containing $18 \%$ protein with starch, six the diet containing $9 \%$ protein with sucrose, and five the diet containing $18 \%$ protein with sucrose. The 
subjects were weighed daily throughout the experiment. Some subjects took part in more than one experiment and their serum proteins had returned to the previous control values before the next dietary regimen began. The serum proteins were examined after an overnight fast before each diet was started and on the 7 th and 16 th days of the diet. They were estimated by a micro-Kjeldahl method after separation by paper electrophoresis (Levin \& Oberholzer, 1953). Details of the method and its reproducibility have been published previously (Coles \& Macdonald, 1966).

\section{Table I. Food quantities provided in a typical diet for I week containing $18 \%$ protein}

\begin{tabular}{|c|c|c|}
\hline & Iunch & Supper \\
\hline Monday & $142 \mathrm{~g}$ lean roast lamb & I $98 \mathrm{~g}$ smoked haddock fillet \\
\hline Tuesday & I $70 \mathrm{~g}$ curried beef & I I $\mathrm{g}$ chicken \\
\hline Wednesday & I 7o g braised steak & I $4 \mathrm{~g}$ lean ham \\
\hline Thursday & $\mathrm{I} 42 \mathrm{~g}$ lean roast lamb & r $7 \circ \mathrm{g}$ hamburgers \\
\hline Friday & $256 \mathrm{~g}$ baked halibut & $142 \mathrm{~g}$ lean roast lamb \\
\hline Saturday & I 4 g chicken chasseur & $170 \mathrm{~g}$ lean roast beef \\
\hline Sunday & $127 \mathrm{~g}$ grilled steak & I 4 g prawns \\
\hline
\end{tabular}

Breakfast: $85 \mathrm{~g}$ lean ham (or lean lamb) daily. Green vegetables or salad were given with each meal. Fresh or unsweetened tinned fruits were given with each meal.

\section{Table 2. Food quantities provided in a typical diet for 1 week containing $9 \%$ protein}

\section{Lunch}

Monday

'Tuesday

Wednesday

Thursday

Friday

Saturday

Sunday
$99 \mathrm{~g}$ lean roast lamb

I $4 \mathrm{~g}$ curried beef

I $4 \mathrm{~g}$ braised beef

$99 \mathrm{~g}$ lean roast lamb

$142 \mathrm{~g}$ baked halibut

$56 \mathrm{~g}$ chicken chasseur

I $56 \mathrm{~g}$ grilled steak

\section{Supper}

I $4 \mathrm{~g}$ smoked haddock fillet

$56 \mathrm{~g}$ chicken

$76 \mathrm{~g}$ lean ham

I $4 \mathrm{~g}$ hamburgers

$156 \mathrm{~g}$ lean baked lamb cutlets

I $4 \mathrm{~g}$ lean roast beef

$5^{6} \mathrm{~g}$ prawns

Green vegetables or salad were given with each meal. Fresh or unsweetened tinned fruits were given with each meal. Fresh grapefruit or salad was provided for breakfast if requested. A daily supplement of $42 \mathrm{~g}$ double cream was given throughout the period.

\section{RESULTS}

The subjects tolerated the diets well and there were no gastro-intestinal disturbances during the experiment. No significant changes in weight were seen with any of the diets. The maximum gain whilst taking any of the diets was $\mathrm{I} \cdot 5 \mathrm{~kg}$ and the maximum loss was $\mathrm{I} \mathrm{kg}$. The mean daily protein intake per $\mathrm{kg}$ body-weight was $\mathrm{I} \cdot 4 \mathrm{~g}$ with the $18 \%$ diets and $0.78 \mathrm{~g}$ with the $9 \%$ diet. On average $70 \%$ of the total calories were obtained from carbohydrate. Table 3 shows the mean values, with standard errors, for each protein fraction during the three experimental periods. The results are expressed in $\mathrm{g} / 100 \mathrm{ml}$ serum and an analysis of variance technique was used for the comparison of the means. The significance of the difference between values on day o and day 16 of the diets is given below.

With all three diets there was a significant fall in serum albumin. With the diet con- 
taining I $8 \%$ protein and sucrose there was a significant increase in both $\alpha_{1}$ - and $\alpha_{2}$ globulins $\left(P=0.005^{-0.001}\right)$. There was no significant change in $\beta$-globulin with the diets containing $18 \%$ protein with starch or $9 \%$ protein with sucrose. With the diet containing $18 \%$ protein with sucrose there was a significant increase in this fraction $\left(P=0.005^{-0.001}\right)$. There was no significant change in $\gamma$-globulin with the diets containing $18 \%$ protein with either starch or sucrose. With the $9 \%$ protein diet with sucrose there was a significant increase in this fraction $\left(P=0.005^{-0.00 I}\right)$.

'Table 3. Mean values with their standard errors for concentration of the serum protein fractions ( $\mathrm{g} / \mathrm{100} \mathrm{ml}$ serum) of young men before eating and while eating a high-carbohydrate diet containing $18 \%$ or $9 \%$ protein

\begin{tabular}{|c|c|c|c|c|c|c|c|c|c|}
\hline & \multicolumn{3}{|c|}{$\begin{array}{l}18 \% \text { protein } \\
\text { with sucrose }\end{array}$} & \multicolumn{3}{|c|}{$\begin{array}{l}\text { I8 } \% \text { protein } \\
\text { with starch }\end{array}$} & \multicolumn{3}{|c|}{$\begin{array}{l}9 \% \text { protein } \\
\text { with sucrose }\end{array}$} \\
\hline Protein fraction & $\begin{array}{c}\text { Day } \\
0 \\
(5)\end{array}$ & $\begin{array}{c}\text { Day } \\
7 \\
(5)\end{array}$ & $\begin{array}{c}\text { Day } \\
\text { I6 } \\
(4)\end{array}$ & $\begin{array}{c}\text { Day } \\
\circ \\
(6)\end{array}$ & $\begin{array}{c}\text { Day } \\
7 \\
(6)\end{array}$ & $\begin{array}{c}\text { Day } \\
\text { I6 } \\
(6)\end{array}$ & $\begin{array}{c}\text { Day } \\
0 \\
(6)\end{array}$ & $\begin{array}{c}\text { Day } \\
7 \\
(6)\end{array}$ & $\begin{array}{c}\text { Day } \\
\text { I6 } \\
(6)\end{array}$ \\
\hline Albumin: mean & $\underbrace{4 \cdot 04}$ & $3 \cdot 78$ & 3.65 & 4.12 & $3 \cdot 94$ & $3 \cdot 8 \mathrm{I}$ & $\underbrace{4 \cdot 15}$ & 3.94 & 3.74 \\
\hline $\mathrm{SE}$ & \multicolumn{3}{|c|}{0.129} & \multicolumn{3}{|c|}{$0.08 \mathrm{r}$} & \multicolumn{3}{|c|}{0.104} \\
\hline$\alpha_{1}$-Globulin: mean & $\underbrace{0.28}$ & 0.32 & 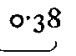 & $\underbrace{0.28}$ & 0.27 & 0.30 & $\underbrace{0.32}$ & 0.28 & $\stackrel{0.28}{\longrightarrow}$ \\
\hline $\mathrm{SE}$ & \multicolumn{3}{|c|}{0.026} & \multicolumn{3}{|c|}{0.006} & \multicolumn{3}{|c|}{0.010} \\
\hline$\alpha_{2}$-Globulin: mean & .48 & 0.50 & 0.56 & 0.55 & 0.50 & $0.5 \mathrm{I}$ & 0.55 & 0.53 & 0.50 \\
\hline SE & \multicolumn{3}{|c|}{0.019} & \multicolumn{3}{|c|}{0.013} & \multicolumn{3}{|c|}{0.014} \\
\hline$\beta$-Globulin: mean & 0.73 & $\underbrace{0.79}$ & 0.84 & $\underbrace{0.79}$ & $\underbrace{0.79}$ & 0.82 & .0 .78 & $\underbrace{0.83}$ & 0.79 \\
\hline SE & \multicolumn{3}{|c|}{0.025} & \multicolumn{3}{|c|}{0.009} & \multicolumn{3}{|c|}{0.013} \\
\hline$\gamma$-Globulin: mean & $1 \cdot 00$ & $\underbrace{0.93}$ & $1 \cdot 08$ & 0.91 & $\underbrace{0.95}$ & 0.91 & 0.83 & $\circ .98$ & $1 \cdot 22$ \\
\hline SE & \multicolumn{3}{|c|}{0.040} & \multicolumn{3}{|c|}{0.012} & \multicolumn{3}{|c|}{ O.roI } \\
\hline
\end{tabular}

Numbers of observations are given in parentheses.

Significance of fall in serum albumin: Diet containing $18 \%$ protein with sucrose, $P=0.05-0.01$; diet containing $18 \%$ protein with starch, $P=0.005-0.00$ I d diet containing $9 \%$ protein with sucrose, $P=0.005-0.001$.

\section{DISCUSSION}

Raw maize starch meals have been given to healthy subjects and the blood glucose concentration has been studied at intervals for up to $2 \mathrm{~h}$ after the meal. These levels showed a sustained rise of up to $20 \%$ over the fasting values (J. N. Crossley, 1967 , unpublished observation). This fact, together with maintenance of weight and the absence of gastro-intestinal disturbance in the subjects in this experiment, suggest that utilization of raw maize starch was adequate.

The changes in serum albumin concentration were similar to those reported previously, and the possible mechanisms involved have been discussed at some length (Coles \& Macdonald, I966). These include diversion of amino acids from liver to muscle consequent upon insulin release (Munro, Black \& Thomson, 1959), loss of albumin from the alimentary tract or alterations in the enzyme content of the pan- 
creatic juice resulting from the high-carbohydrate diet. In this experiment the striking feature was that changes in the $\gamma$-globulin concentration were only seen in the subjects receiving the diet containing $9 \%$ protein. The association between low serum albumin concentrations and elevated $\gamma$-globulin levels has been frequently reported in man and animals (Bjørneboe, 1945 $a, b$; Sussman \& Freed, 1950; Bjørneboe \& Schwartz, 1959; Catsoulis, Franklin, Oratz \& Rothschild, 1964; Rothschild, Oratz, Mongelli \& Schreiber, 1965). The explanation proposed by Rothschild et al. for this association is that the $\gamma$-globulin is compensating for the lowered colloid osmotic pressure of the plasma resulting from the fall in albumin concentration. Thus a primary fall in albumin concentration is followed by an increase in $\gamma$-globulin and high levels of serum globulin such as are seen after immunization are accompanied by falls in albumin. Some confirmatory evidence for this theory was put forward by Bjørneboe $(1945 b)$, who found that the serum albumin and $\gamma$-globulin levels in patients with hepatitis showed a negative correlation. This relationship between albumin and $\gamma-$ globulin was used to predict an equation between the two fractions to maintain a constant osmotic pressure. Patients free from ascites conformed to the predicted levels, but all except two patients with ascites had serum protein concentrations far removed from the predicted values for the maintenance of osmotic pressure. Bjørneboe suggested that in these patients the compensatory mechanism had failed. It seems most unlikely that this mechanism can be incriminated in these experiments as the fall in albumin was slightly greater on the diets containing $18 \%$ protein when no change was apparent in the $\gamma$-globulin fraction. Cohen \& Hansen (1962), using an isotopic technique, have studied the metabolism of both albumin and $\gamma$-globulin in children with severe protein-calorie malnutrition. They found the synthesis and fractional breakdown of albumin much reduced, whereas the synthesis and turnover rate of $\gamma$-globulin were unchanged except during infections when it was enormously increased. They concluded that when protein intake was restricted the cells responsible for $\gamma$-globulin synthesis preferentially utilized amino acids. The protein intake of $0.78 \mathrm{~g} / \mathrm{kg}$ bodyweight daily in these experiments should be sufficient for maintenance of normal plasma protein metabolism but it is possible that the imbalance of dietary constituents produced by high carbohydrate intake renders the $9 \%$ diet inadequate. Jeffay $\&$ Winzler (1958) found no evidence of changes in the metabolism of $\gamma$-globulin in protein-deficient rats and concluded that the turnover of serum albumin was dependent on the level of dietary protein but that of the $\gamma$-globulin was not. Freeman \& Gordon (I964), however, also working with rats, found that the fractional and absolute rates of catabolism of $\gamma$-globulin were reduced on a protein-free diet. In their experiments starch and sucrose replaced the protein in the experimental diets resulting in a great increase in the proportion of calories derived from carbohydrate. In both animal experiments (Freeman \& Gordon, 1964) and in naturally occurring protein-calorie malnutrition there is an abnormally high percentage of carbohydrate calories in the diet although the total calorie intake may be deficient. In the present experiment the protein intake on the diets containing $18 \%$ protein was high, but despite this the albumin fraction decreased. This would suggest that the carbohydrate plays some part in the alteration of albumin metabolism. An increase in the $\gamma$-globulin fraction was 
seen only with the diet containing $9 \%$ protein, which suggests that the level of dietary protein does influence the metabolism of $\gamma$-globulin even in the absence of antigenic stimulation. However, the diet containing $9 \%$ protein contained an average of $6_{5} \mathrm{~g}$ of fat compared with an average of $47 \mathrm{~g}$ in the diets containing $18 \%$ protein and it is possible that this increased fat intake was responsible for the higher $\gamma$-globulin levels observed after eating the diet containing $9 \%$ protein. This possibility is at present under investigation.

There remains the increase in $\beta$-globulin concentration which was seen in subjects receiving the diets containing $18 \%$ protein with sucrose, but not in those receiving either of the other diets. In subjects receiving the diet containing $18 \%$ protein with sucrose there was also a marked rise in triglyceride level (I. Macdonald, 1967, unpublished observation). This increase in triglycerides did not occur with the other diets. It is known that triglyceridaemia affects mainly the pre- $\beta$-lipoprotein fraction. With the method of protein estimation used in this investigation an appreciable amount of pre- $\beta$-lipoprotein would be estimated with the $\beta$-globulin fraction and it is suggested that this is reflected in the increase in $\beta$-globulin that was observed with the diet containing i $8 \%$ protein with sucrose. In protein-calorie malnutrition this fraction remains unchanged or is reduced, but in these instances the carbohydrate is not usually sucrose and the total calorie intake is often deficient; a rise in triglycerides would not be expected.

Increases in both $\alpha_{1}$ and $\alpha_{2}$-globulins have been reported in numerous conditions in which there is a decrease in the albumin fraction. Such changes appear to be nonspecific and might have been expected to occur with all the diets. No satisfactory explanation can be advanced for the fact that these fractions only increased with the one diet.

I am very grateful to the students who acted as subjects, and to the Department of Dietetics, in particular Miss Heney, for arranging the experimental diets.

\section{REFEREN CES}

Bjørneboe, M. (1945a). Acta path. microbiol. scand. 22, 323.

Bjørneboe, M. (1945b). Acta med. scand. 123, 393.

Bjørneboe, M. \& Schwartz, M. (1959). F. exp. Med. I10, 259.

Catsoulis, E. A., Franklin, E. C., Oratz, M. \& Rothschild, M. A. (rg64). 7. exp. Med. Ir9, 6r 5.

Cohen, S. \& Hansen, J. D. L. (1 962). Hand. VoedVeren. suid. Afr. 3, 26.

Coles, B. L. \& Macdonald, I. (1966). Clin. Sci. 30, 37.

Freeman, T. \& Gordon, A. H. (1964). Clin. Sci. 26, I7.

Jeffay, H. \& Winzler, R. J. (r958). F. biol. Chem. 23r, II I.

Levin, B. \& Oberholzer, V. G. (I953). Am. F. clin. Path. 23, 205.

Munro, H. N., Black, J. G. \& Thomson, W. S. T. (1959). Br. Ұ. Nutr. 13, 475.

Rothschild, M. A., Oratz, M., Mongelli, J. \& Schreiber, S. S. (1965). F. Lab. clin. Med. 66, 733.

Sussman, R. M. \& Freed, S. Z. (1950). Proc. Soc. exp. Biol. Med. 73, 359. 